\title{
Filosofický seminář na Filosofické fakultě Masarykovy univerzity v letech 1919-1925
}

\section{The Philosophical Seminar at the Faculty of Arts of Masaryk University in 1919-1925}

\author{
Jiří Gabriel
}

Před časem jsem se pokusil načrtnout dějiny brněnského Filosofického semináře (potom katedry) Masarykovy univerzity. ${ }^{1} \mathrm{~V}$ souvislosti se stým výročím vzniku ČSR a následným ustavením Masarykovy univerzity ${ }^{2}$ se vracím k prvním létům Filosofického semináře (FS), abych některé pasáže ve výše zmíněné stati doplnil několika dalšími údaji. Především mi jde o zjištění, odkud jeho zakladatelé a první pedagogové přicházeli, co je k tomu motivovalo a jak byli na své poslání připraveni. Ucelenější informace o jejich filosofických a vědeckých názorech, společenských stanoviscích, badatelských cílech,

1 GABRIEL, J. Filosofie na brněnské univerzitě v letech mezi dvěma světovými válkami. Vlastivědný věstnik morauský 1968, XX, s. 62-77. [Viz také stručnější text GABRIEL, J. Brněnský filozofický seminár. In Sbornik praci Filozofické fakulty brněnské univerzity, 1993, B40, s. 7175.] - Výraz seminár má dva významy: Jednak označuje fakultní ústav (instituci) pro výuku nějakého vědního oboru, jednak fakultní výuku s programem doplňujícím přednášky, tedy seminární cvičení, četbu a výklad vybraných textů, řečnická cvičení, psaní a čtení referátů na zadaná témata, diskuzní debaty apod. Na „seminární“ činnosti kladli učitelé FS od počátku velký důraz, protože studenty orientují k jejich vlastní odborné práci. Seminární četba a výklad cizojazyčných publikací přispívá i k jazykovému (překladatelskému) vzdělávání studentů. Přípravu posluchačů na seminární činnosti představují tzv. „prosemináře“. V každém studijním roce se vypisovala filosofická přednáška doporučená pro posluchače všech oborů.

2 Viz např. JORDÁN, F. a kol. Dějiny Univerzity v Brně. 1969. Návrh na „zřízení druhé české univerzity s českou vyučovací řečí v Brně“ předložili Národnímu shromáždění poslanci (Alois Jirásek, Karel Engliš ad.) 15. 11. 1918, a ustavena byla 28. ledna 1919 Zákonem č. 50/1919 Sb., „ozdobena jménem prvního prezidenta Tomáše Garrigue Masaryka“. 
publikacích apod. čtenáři najdou ve Slovniku českých filosofů (Brno 1998) a v monografických publikacích, na něž př́ležitostně odkazuji.

Filosofická fakulta získala pro svou činnost budovu postavenou v 1. 18711872 na Falkensteinerově ulici (dnes Gorkého) pro městský sirotčinec. ${ }^{3}$ Fakulta v ní k naplňování svého poslání - vzdělávání studentů v humanitních vědních disciplínách - zřídila oborové ústavy, tehdy zvané semináře, později katedry. Filosofický seminár̆, který byl ustaven jako jeden z prvních, dostal prostory pro pracovny učitelů a posluchárnu v jejím př́izemí. Zvláštností FS FF MU bylo, že se ve svých počátcích (prvních pěti letech) členil na oddělení filosofické (označované za všeobecné) a na oddělení specifická: psychologické, pedagogické, sociologické a hudebně vědecké. Tato oddělení byla iniciována „mimofilosofickým“ (resp. filosofii provázejícím) odborným zaměřením členů FS, které spojovali s filosofií a její výukou, a to v čase, kdy vědní obory těchto oddělení neměly na brněnské FF vlastní semináře. $\mathrm{V}$ rámci FS měla tato oddělení své vedoucí/ředitele (z členů FS), kteří se starali o to, aby byla vybavena potřebnými pomůckami pro bádání i výuku, především odbornými publikacemi domácí i zahraniční provenience a různou technikou (šlo o „náležité vyzbrojování oddělení“). Např. O. Zich pro hudebně vědní oddělení a výuku estetiky prosadil zakoupení klavíru, gramofonu, souboru not a hudebních nahrávek a na nákupy knih pro oddělení FS posílal jejich zástupce i do zahraničí. Dochovaná korespondence FS s vedením fakulty z té doby svědčí o četných a nemalých příspěvcích, které FS získával pro svá oddělení (i na odměny pro pomocné síly). Když se později (se stavbou nových budov fakulty) organizovaly další oborové semináře, předal FS nashromážděnou „výbavu“ svých oddělení jejich nástupným seminářům.

Výuka na fakultě byla zahájena 1. září $1921 .{ }^{4}$ Učební programy studijních oborů byly publikovány v tištěných Seznamech prédnášek. První, datovaný

3 Budovu nechal postavit brněnský podnikatel a mecenáš Valentin Falkensteiner (18001884); jejím architektem byl Josef Arnold, stavitelem Moritz Kellner von Brünnheim (viz Internetová encyklopedie města Brna). Dnes se budova (s označením „A“) nachází v areálu FF s adresou Brno, Arna Nováka, č. 1.

4 Na brněnské FF od počátku existovaly semináře filosofický, historický, filologie klasické, slovanské, germánské, románské, později se dále ustavily (resp. osamostatnily) seminář psychologický, sociologický, pedagogický, estetický, hudební aj. Posluchači si většinou zapisovali dvouoborové studium (a navíc, po dohodě s přednášejícími, mohli poslouchat další zvolené přednášky). V každém studijním roce se vypisovala filosofická přednáška doporučená pro posluchače všech oborů. - Do prvního ročníku se ke studiu přihlásilo celkem 128 studentů; v letním semestru ak. r. 1924/25 jich už bylo 280. Na čtyřech fakultách měla MU $\mathrm{v}$ tom roce 1503 posluchače. 
na akademický rok 1920/1921, měl úkol jen obecně informační: představoval fakultu, její poslání, uspořádání a formy studia. Výčet přednášek a seminárních cvičení přinesl Seznam na ak. r. 1921/22. Počínaje dalším školním rokem Seznamy vycházely zvlášt pro zimní a letní semestr. O přednáškách členů FS se zmiňuji v další části tohoto článku. - Pozoruhodné bylo, že když byly v ak. roce 1922/23 z původních oddělení FS ustaveny další (specifické) fakultní semináře, byly v Seznamech všechny jejich přednášky a seminární cvičení řazeny pod společné označení Vědy filosofické a pedagogika.

Univerzitní semináře (jako dílčí fakultní instituce) byly vždy záležitostí především pedagogů, kteří v nich působili. Brněnský FS měl štěstí, že jeho zakladatelskými postavami byly výrazné osobnosti z českého univerzitního života. Jeho ředitelem se stal prof. Otakar Zich (1879-1934). Na úkol zřídit a vést FS byl dobře připraven. V letech 1897-1901 studoval na UK matematiku, fyziku a estetiku (u Otakara Hostinského), kde se také v r. 1911 habilitoval z estetiky. Poté získával zkušenosti se středoškolskou výukou na gymnáziu v Domažlicích. V letech 1919-1923 dojížděl do Brna přednášet na FF o filosofii a psychologii pro všechny posluchače fakulty. Jako znalec a milovník umění se snažil své posluchače filosofie zaujmout také přednáškami (hovory) o umění a estetice; jistě je přitom upoutával svými úvahami o uměleckém poznání a problému umělecké pravdivosti. Po splnění svého brněnského poslání se Zich vrátil na FF UK, na níž obnovil a vedl Estetický seminář. Po něm tuto funkci převzal jeho žák Jan Mukařovský.

Dalším pedagogem, jenž s bohatými odbornými znalostmi a pedagogickými zkušenostmi působil v brněnském FS od jeho počátku až do r. 1939 (a pak ještě po válce), byl Inocenc Arnošt Bláha (1879-1960). Pro jeho osobnost je příznačné, že když po maturitě na gymnáziu v Pelhřimově (1897) vstoupil do bohosloveckého semináře $\mathrm{v}$ Hradci Králové, byl z něho brzy vyloučen pro svobodomyslné názory. Svou př́ípravu na učitelské povolání pak svěřil univerzitám v Praze, Vídni a Paříži; do Paříže se vypravil znovu v letech 19081909 na studijní pobyt u sociologů E. Durkheima a L. Lévy-Bruhla. V letech 1904-1919 učil na reálce v Novém Městě na Moravě. Doktorát z filosofie získal na UK v r. 1908 za spis Duše malého města. V r. 1916 se na brněnské Vysoké škole technické habilitoval prací (jak ji sám charakterizoval) „z filosofie se zvláštním zřetelem k sociologii“: Město: Sociologická studie. V r. 1919 byla jeho habilitace uznána i pro obor filosofie, a tak v prosinci 1920 Bláha mohl přejít na FF MU. (V prvním Seznamu přednášek je představen ještě jako suplent praktické filosofie se zřetelem k sociologii na České vysoké škole technické a profesor gymnázia v Praze na Křemencově ulici.) V prosinci 1921 prezident 
T. G. Masaryk jmenoval Bláhu mimořádným profesorem sociologie a ministr školství V. Šrobár jej vyzval k složení předepsané př́sahy ${ }^{5}$ a k tomu, aby „radou i činem spolupůsobil při organizování FF a zastával obor, pro který byl jmenován“. 6

V ak. roce 1922/23 se dalším členem FS FF MU stal Josef Turdý (1877-1942). Na gymnáziu v Jičíně náležel k jeho učitelům filosof a psycholog Oldřich Kramář, herbartovec, o němž Josef Král v Československé filosofii (1937) napsal, že patřil k několika málo metafyzikům, jimiž se může vykázat česká filosofie. Po maturitě (1896) zapisoval Tvrdý na FF UK filosofii a klasickou filologii. Filosofii tam tehdy přednášeli Durdík, Masaryk, Drtina, Čáda a Krejčí; Tvrdý se považoval především za žáka Masarykova a Drtinova. ${ }^{7}$ Státní práci z filologie na téma $O$ filosofii stoiku mu zadal profesor klasické filologie Robert Novák (z české FF UK), práci z filosofie na téma Proč uč Platon pedagogice ve spise o státě Masaryk. Po zkouškách z latiny pro učitelství na nižších gymnáziích a z řečtiny a filosofické klasické propedeutiky na gymnáziích vyšších (později získal ještě aprobaci z franštiny) začal vyučovat na Matičním gymnáziu ve Vyškově. Když se přitom - veden př́íladem svých univerzitních učitelů, zejména Masaryka a Drtiny - energicky účastnil tamního kulturního a politického života, brzy si jako „masarykovec a volnomyšlenkář“ vysloužil kritickou pozornost klerikální Moravské orlice. Podobně působil i jeho doslov k novému vydání Paměti kněze z církve vyobcovaného od Augustina Smetany. ${ }^{8}$ V r. 1914 byl

5 Tehdejší učitelé (jako státní zaměstnanci) při nástupu přísahali: „Přísahám a slibuji na svou čest a svědomí, že Česko-slovenské republice budu vždy věren a její vlády poslušen, budu veškery státní zákony zachovávati, své úřední povinnosti dle platných zákonů a nařízení vykonávati pilně, svědomitě a nestranně, úředního tajemství neprozradím a ve všem jednání jen prospěji státu a zájmu služby budu dbáti.“

6 S ohledem na Sociologické oddělení FS lze říci, že Bláha „založil Sociologický seminář na FF MU v r. 1922 a řídil jej do r. 1939 a pak ještě v letech 1945-1949“. K Bláhově brněnské sociologické škole se hlásili Antonín a Juliána Obrdlíkovi, Bruno Zwicker, Bedřich Václavek, Mojmír Hájek ad., z mladších Ivo Možný. Syntézu svého obsáhlého sociologického díla Bláha podal ve své Sociologii (1968).

7 Drtina si Tvrdého získal „kouzlem své osobnosti a svým vášnivým zaujetím pro myšlenku humanismu“ (Moderni proudy ve filosofi, 1925). V článku „Drtina filosof“ (Naše doba, 1925) vyzdvihl tezi A. Fouilléeho: „Kořeny filosofie tkví tam, kde se tvoří harmonie objektivního světa se světem subjektivním, když objektivní pravda je pronikána lidskou osobností, která z rozbíhavé objektivní pravdy vytváří jednotný obraz světa."

8 Josef Tvrdý byl častěji považován za pozitivistu. Avšak po spisech Problém skutečnosti u Davida Huma (1925) a Teorie pravdy (1929) odmítl v Nové filosofii (1932) koncept nepoznatelného transcendentna a přihlásil se k teorii emergentního vývoje, v níž viděl možnost vyložit vznik nových vyšších kvalit, a k monopluralismu, chápajícímu skutečnost jako vnitřně diferencovaný celek, jednotu v rozmanitosti. V Nové renesanci vyslovil naději, že příští renesance 
Tvrdý přeložen do Brna na II. České státní gymnázium, ale místo do školy narukoval na vojnu, kterou prožil jako důstojník zdravotnické služby u těžkého dělostřelectva. - V r. 1920 za spis Filosofie náboženství získal doktorát filosofie na UK a v zimním semestru ak. r. 1922/23 začal přednášet na FF MU. Po dvou letech Bláha a Chlup podali návrh na jeho jmenování mimořádným profesorem, ale učitelský sbor FF návrh označil za předčasný. Tvrdý proto přestoupil na bratislavskou $\mathrm{FF}$, kde byl hned jmenován řádným profesorem a na ak. r. 1932/33 zvolen děkanem fakulty. ${ }^{9} \mathrm{~V}$ Brně nadále přednášel jen 2 hodiny týdně a pouze v jednom semestru (šlo nejčastěji o „čtení“ z noetiky, logiky a dějin filosofie). V listopadu 1938 se Tvrdý z Bratislavy vrátil na MU, kde jej profesor J. L. Fischer navrhl na spoluředitele FS. Přednášet tu však mohl necelý rok. Po uzavření českých vysokých škol odešel na předčasný odpočinek, ale ani ten netrval dlouho. Antifašista, celým svým intelektuálním, mravním a politickým zaměřením obhájce mravních hodnot a demokracie, byl v prosinci 1941 zatčen gestapem, v únoru 1942 převezen - s proslulým „R. U.“ (tj. „návrat nežádoucí“) - do koncentračního tábora v Mauthausenu, kde 13. března 1942 zahynul.

V ak. r. 1921/22 byl učební program studentů FS rozšířen/obohacen o čtení a výklad Platonova dialogu Gorgias. Učitelé FS si nejspíše přáli seznámit své posluchače nejen s tímto Platonovým proslulým dílem, ale také představit jim profesora klasické filologie Karla Svobodu (1888-1960) z brněnského Semináře řeckého a Prosemináře pro klasickou filologii, překladatele latinských a řeckých filosofických textů a autora mnohých publikací z dějin antické a středověké filosofie. ${ }^{10}$

$\mathrm{Z}$ učebních programů FS je zřejmé, že se v něm přikládal značný význam psychologii jako vědě mající blízko $\mathrm{k}$ filosofii (dlouho byla považována za filosofickou disciplínu). Byla brána jako nauka přispívající lidem (a filosofům a pedagogům zvláště) k adekvátní interpretaci vnímané skutečnosti, k hlubšímu porozumění osobním zážitkům, vlastním i cizím názorům, hodnotícím soudům, motivačním rozhodnutím atp.

povede k vytvoření humanitní společnosti. (Tvrdého spisy o racionální indukci, humanitě a humanismu zůstaly nedokončeny.) - Řadu příspěvků o vývoji a proměnách českého pozitivismu publikoval Jiří Cetl.

9 Účast Josefa Tvrdého na rozvoji slovenské filosofie v třicátých letech 20. století jsem naznačil v knize Filosofie Josefa Turdého. K dějinám české filosofie mezi dvěma světovými válkami, Brno: Univerzita J. E. Purkyně 1982.

10 S některými členy z těchto ústavů se posluchači filosofie setkávali jako se svými učiteli latiny. 
V brněnském FS se v letech 1921-1925 o náležité psychologické znalosti posluchačů spolu s O. Zichem a I. A. Bláhou staral zejména profesor Otokar Chlup (1875-1965), který ve své výuce v Brně zčásti napodobil, co sám v letech 1895-1900 zažíval při studiu francouzštiny a češtiny na UK, kde navštěvoval rovněž přednášky z filosofie a pedagogiky: Masaryka, Drtiny, Krejčího, Kádnera a Čády. Předností Chlupových výkladů bylo, že poučení z psychologie spojoval s poučením z pedagogiky. V 1. 1899-1903 učil na středních školách, v r. 1901 dostal studijní volno na zkušenou v Anglii a Švýcarsku. Dizertační práci napsal na téma Ideál výchovy u Montaigna a Locka. Jako středoškolský profesor psal a překládal články s psychologickou a pedagogickou tematikou, např. Kulturni boj o školu, Vývoj citů a vi̊le aj. V r. 1920 se habilitoval na UK spisem Pamět, studie z pedagogiky psychologické. Do Brna jej - člověka se širokými kulturními zájmy - v r. 1922 zlákalo založení MU a výborná pověst brněnských kulturních institucí, především opery. V roce 1922 byl v Brně jmenován mimořádným profesorem a ředitelem Pedagogického semináře. Velmi mu záleželo na zkvalitnění př́ípravy středoškolských profesorů i učitelů obecných a měštanských škol. K řádné profesuře napsal spisy (v „intencích pozitivistické metodologie“) Vývoj duševních projevů dětí méně schopných a Vývoj pedagogických ideji v novém věku. V r. 1925-1932 z jeho podnětu fungovala při pedagogickém semináři FF MU pokusná třída pro nadané děti. Zkvalitnění učitelského působení na školách se věnoval až do svého penzionování $\mathrm{v}$ roce 1940.

Studenti brněnského FS měli štěstí také v tom, že mohli osobně poznat docenta Emanuela Chalupného (1879-1958), poněvadž tento vynikající myslitel spojoval svůj život a působení především s Prahou a svým rodným Táborem. V r. 1898 maturoval na táborském gymnáziu a poté studoval v Praze na Právnické a Filosofické fakultě (filosofii a sociologii). Jeho univerzitním učitelem byl i T. G. Masaryk, který v něm brzy poznal nadaného studenta mimořádně kulturně i politicky vyspělého a vyzval ho, aby se stal členem Pokrokové strany. V r. 1903 Chalupný získal doktorát práv a Masaryk mu nabídl, aby se stal členem vedení strany (v Čase už řídil vnitropolitickou rubriku). Chalupný se však jako kritický myslitel dostal do rozporu s některými jejími předními členy (Herbenem, Macharem) a ze strany vystoupil. V letech 1910-1920 se v Táboře (spolu s literární činností) věnoval advokacii. K řešení právnických případů přistupoval sociálně citlivým, „sociologizujícím zpo̊sobem“, a i proto se mu dostávalo tentokrát odsudků a kritik nejen od jiných advokátů, ale zejména od pražských a brněnských právních vědců-normativců, čímž přišel o možnost habilitovat se z právní vědy na UK i MU. Filosofická fakulta MU 
však k vědecko-pedagogickému ocenění Chalupného rozsáhlého a tematicky bohatého díla přispěla tím, že jeho brněnskou habilitaci v roce 1923 doplnila mimořádnou profesurou sociologie v roce 1936. - Chalupného myšlenkový vývoj (ovlivněný pozitivismem), jeho pojetí vědy, filosofie, sociologie (Chalupný se podílel na založení a redigování brněnské Sociologické revue), příspěvky k českým dějinám národním i literárním výstižně charakterizuje Jaroslav Hroch ve Slovniku českých filosofü. ${ }^{11}$

Jako poslední v letech 1919-1925 doplnil pedagogickou sestavu FS FF MU Mihajlo Rostohar (1878-1966). Již jeho jméno napovídá, že tento u nás první experimentální psycholog a řádný profesor psychologie na MU byl Slovinec (narozený v Bregach u Krška). Svým spiskem Národnost a jeji mravni význam (vyšel v Praze nákladem Menšinového muzea r. 1946) se projevuje jako hluboce cítící vlastenec, promýšlející vztah člověka/jedince a jeho národa, povinnosti a úkoly, které oběma členům z toho vztahu plynou. Už v raném mládí nabyl přesvědčení, že $\mathrm{k}$ mravním povinnostem člověka patří i péče o osobní vzdělání, podmiňující možnosti jednotlivce přispívat k úrovni národního společenství. - Po vídeňské maturitě (1901) začal univerzitní studia: ve Vídni medicíny a přírodních věd a (od 1903) ve Štýrském Hradci filosofie (noetiky) a psychologie. Ve Štýrském Hradci na Rostohara silně zapůsobil profesor Alexius Meinong svou experimentální psychologií a jí inspirovanou ontologií, založenou na rozlišování různých způsobů existence poznávaných „objektů“: jednak předmětů (objektivně) reálných, jednak (jen) myšlených či představovaných, fantastických. ${ }^{12}$ Po vídeňském doktorátu filosofie (1905/6 za dizertaci Ueber der Hypothesen und ihre erkenntnistheoretische Bedeutung) strávil Rostohar ještě dva roky ve Wundtově Psychologickém ústavu v Lipsku. Rostoharovo další vědecké putování podnítil profesor Jodl z Vídně, když ho doporučil Masarykově pozornosti, a Masaryk mu zprostředkoval přestup na FF UK (i s jeho soukromou laboratoří experimentální psychologie). ${ }^{13}$ V r. 1911 se Rostohar u něho habilitoval spisem Theorie hypotetického soudu

11 O Chalupného brněnské habilitaci, profesuře a jeho činnosti v Sociologické revui píše H. Pavlincová v příspěvku Chalupný a Brno. In ZUMR, J. (ed.). Emanuel Chalupný, česká kultura, česká sociologie a Tábor. Praha: Filosofia 1999, s. 23-31.

12 Rostohar smyslové vjemy pokládal za ovládané psychickými zákony, z danosti smyslových vjemů (počitků) odvozoval i rozmanité útvary jako hodnoty estetické, etické, sociální, jichž žádnými kvantitami nelze zachytit, protože to jsou kvality kvantitami nenahraditelné. Tato cesta vedla Rostohara také ke kategorii psychické struktury a ke strukturálnímu myšlení.

13 Masaryka s Rostoharem spojovaly nejen vědecké a pedagogické zájmy, ale také zájmy politické, zejména vývoj vztahů slovanských národů. Rostoharův názor, že ,jižní Slovany lze nově politicky sjednotit jen na zásadě sebeurčení balkánských národů“, byl (podle 
a začal přednášet filosofii a psychologii. V r. 1915 musel narukovat do armády. Po válce chtěl působit na univerzitě v Lublani, na jejímž založení se podílel, avšak neshody s místními činiteli jej přiměly k návratu do Prahy. Tam se však názorově rozcházel s F. Krejčím, s jeho přednáškami psychologie a logiky, a tak uvítal možnost přednášet na MU, když sem byla v r. 1923 přenesena jeho pražská habilitace. Inovační pojetí jeho disciplín tu mělo dobrý ohlas, a tak v dalším roce byl jmenován mimořádným profesorem systematické filosofie a po Zichově návratu na UK pověřen vedením FS. Významný byl pro Rostohara i rok 1925, protože 7. 5. ministr školství povoluje, aby se oddělení pro experimentální psychologii při FS osamostatnilo jako Psychologický ústav. Rostohar se stal jeho ředitelem, když obé podpořil profesor Edward Babák, tehdejší rektor MU. ${ }^{14}$

Přestupem na Psychologický ústav Rostohar uvolnil svůj dosavadní „post“ ve FS. Tak se mohl o toto místo ucházet Vladimír Hoppe (1882-1931). Hoppe sice nezapadá do první FS „pětiletky“, ale časem byl v české filosofii nejčastěji jmenován právě v souvislosti s výše zmíněnými osobnostmi. Málem však k jeho přijetí do FS vůbec nedošlo: V roce 1927 měl Hoppe publikovánu většinu svých hlavních prací, v nichž se hlásil k iracionalistické a intuitivistické filosofii. Vzhledem k filosofické orientaci stávajících členů semináře ${ }^{15}$ by se jejich souhlas s Hoppeho účasti ve FS neobešel bez pochybností, ale posléze vzali v úvahu stanovisko brněnské komise z r. 1925 k Hoppeho mimořádné profesuře: „Komise sice nepřijímá za své všecky názory, k nimž Hoppe došel svými úvahami o poměru filosofie $\mathrm{k}$ vědám, a zvláště o významu vědeckého poznání skutečnosti, jakož i o pojetí intuice i jejího noetického významu, avšak uznávajíc jeho neobyčejný rozhled filosofický a schopnost k filosofické koncepci dokázanou jeho dosavadní literární činností, podává návrh, aby byl jmenován mimořádným profesorem. Prof. Bláha a Chlup se nepřidávají k tomuto návrhu, poněvadž jsou toho mínění, že by se při obsazování stolice filosofie neměli předem vylučovati jiní docenti filosofie, kteří by mohli even-

L. Koláříkové) jedním z důvodů, proč Lublaňská univerzita odmítla návrh na Rostoharovu habilitaci a proč on zvolil po první světové válce návrat do Prahy.

14 Výklad o Rostoharově životě a díle podala doc. PhDr. Ludmila Koláříková (1909-1968) v obsáhlém nekrologu „Prof. Mihajlo Rostohar zemřel v pátek dne 5. srpna 1966“, uveřejněném ve Sborniku praci FF brněnské univerzity, Řada pedagogicko-psychologická 1967, roč. 16.

15 V rámci filosofie se něčím - alespoň v nějaké míře - navzájem liší snad všichni filosofové. Platí to také o všech prvních členech FS FF MU, i když se shodovali v záměru pěstovat „filosofii skladby a řádu skutečnosti“ s využitím poznatků smyslových i racionálních, zkušenostních i vědeckých. 
tuálně přijít v úvahu.“ - Hoppeho mládí je spojené s Kroměříží, kde po sextě gymnázia soukromě studoval chemii, medicínu a farmacii, experimentoval v soukromé laboratoři a nějaký čas byl zaměstnán v lékárně. Po maturitě v r. 1901 odešel do Prahy studovat na UK, zajímal se především o Masarykovy přednášky. V r. 1907 získal doktorát filosofie a v r. 1922 se na UK habilitoval. V roce 1926 nastoupil na FF MU na místo po Rostoharovi, které si podržel až do r. 1931. V roce 1970 vydal Robert Konečný ve Spisech brněnské univerzity knihu Vladimír Hoppe. Př́spěvek k historii a kritice iracionalismu. Hoppeho filosofii v ní nejstručněji charakterizoval tak, že v „Závěru“ přidal k titulům jeho hlavních publikací větu o jejich obsahu: (1914) Podstata a hodnota přírodovědeckého poznání: popření možnosti vědeckého světového názoru jako názoru filosofického; (1918) Příroda a věda: naturalistický panteismus, dynamický iracionalismus; (1922) Základy duchovni filosofie: kolísání mezi mystickým panteismem a intuitivním expresionismem, transcendentální idealismus; (1925) Přirozené a duchovni základy světa a života: překonávání transcendentálního idealismu, kolísání mezi panteistickou a křestanskou mystikou; (1928) Úvod do intuitivni a kontemplativni filosofie: filosofie jako metoda ve službách křestanství; (1935) Předpoklady duchovni filosofie a náboženské víry: odhození filosofie a přijetí náboženské víry.

Profesor Arne Novák (1880-1939) nebyl členem FS, nicméně do výukového (seminárního) programu 2. ročníku studia filosofie byla zařazena jeho „Četba a výklad Máchova Máje“. Je možné, že k tomu dal podnět sám Novák svou vstupní přednáškou na FF MU 22. 11. 1921 s názvem „Problémy moravské kultury“. Studentům filosofie pomohl uvědomit si rozdíl mezi prostým „filosofováním“ a filosofií jako specifickým kulturním útvarem a zároveň poznat, jak lze vědecky, a tedy i kulturně přistupovat k populárnímu literárnímu dílu, jež se nejen v minulosti, ale i přítomnosti setkává s rozporným hodnocením. Arne Novák si ovšem zasloužil, aby ho studenti blíže poznali i jako osobnost, která podstatně přispěla k pracovnímu rozjezdu a dalšímu zdárnému vývoji fakulty, a to nejen svými univerzitními funkcemi, ale i zdůrazňováním, že k vědecké a pedagogické činnosti patří také poučené a poctivé zacházení s českým jazykem a českou řečí. Protože se Novák už v roce 1920 mohl vykázat dvojí habilitací a řádnou profesurou, nacházíme jeho podpis i na doporučeních děkanátu k přijetí nových uchazečů o pedagogické působení na FF. ${ }^{16}$

16 Arne Novák se narodil v Litomyšli, gymnázium navštěvoval v Litomyšli a Praze, kde v r. 1898 maturoval. Poté na UK zapisoval germanistiku a bohemistiku (rok 1901 strávil na univerzitě v Berlíně). V letech 1903-1919 učil na gymnáziích v Praze a Kutné Hoře. V roce 1906 se 


\section{Přednáškový program Filosofického semináře FF MU}

Přehled ukazuje, jak a čím jednotliví členové FS v daném období přispěli $\mathrm{k}$ výuce studentů filosofie. Č́́slice v závorce za názvem přednášky uvádí počet hodin věnovaných jí týdně v daném akademickém roku, v zimním, nebo letním semestru. Semestry („běhy“, jak se ř́kalo) v tomto přehledu nerozlišujeme; pokud se některá přednáška konala v obou pololetích, následují za ní dvě číslice.

Ak. rok 1921/22

Zich: Úvod do psychologie (3, 3), Poetika (2, 2), Seminární cvičení (2).

Bláha: Základy sociologie (2, 3), Filosofie dějin (2), Praktická filosofie (4), Sociologická cvičení $(2,2)$.

Vědy filologické

Svoboda: Řečtí myslitelé od Thaleta po Sokrata (2), Aristoteles (2).

Novotný: Výklad Platonových listů (2).

Proseminář pro klasickou filologii

Svoboda: Čtení a výklad Platonova Gorgia (2).

Ak. rok 1922/23

Zich: Dějiny novodobé psychologie (3, 2), Česká metrika (2, 2), Problém umělecké originality (1), Seminární cvičení $(2,2)$.

Bláha: Filosofie mravnosti (4), Základy sociologie (přírodní, psychofysičtí, sociální činitelé života společenského) (2, 3), Filosofie národnosti (2), Sociologická cvičení $(2,2)$.

Turdý: Logika, část elementární (2, 2), Logika. Vědosloví (2).

Chlup: Dějiny pedagogických teorií v novém věku (1), Experimentální pedagogika (4), Sternova psychologie (2), Práce písemné a jejich kritika (2).

Seminář pro slovanskou filologii

Novák: Výklad a rozbor Máchova Máje (2).

Proseminář pro klasickou filologii

Svoboda: Čtení Aristotelovy Poetiky (2).

na UK habilitoval z německé literatury a 1910 z dějin české literatury. Řádnou profesuru získal v r. 1920 na MU, na níž byl $(1938,1939)$ zvolen rektorem (rektor se volil na jeden rok). Když v r. 1921 přesídlil do Brna, stal se stálým členem redakce Lidových novin. Novák měl k filosofii blízko, nijak se nevyhýbal filosofickým úvahám, at ve vlastních pracích, či při kritikách různých cizích textů, k nimž shledal nějaké podněty. 
Ak. rok 1923/24

Zich: Psychologie smyslů (2, 2), Estetika výtvarného umění (3, 3), Psychologická cvičení $(2,2)$.

Bláha: Základy sociologie (společenská statika) (2, 3), Experimentální psychologie (1), Prvky a složky společenského života (3), Úvod do vědy politické (2), Praktická filosofie (4), Sociologická cvičení (2), Filosofický seminář (2).

Chlup: Dějiny pedagogických teorií v novém věku (1), Kapitoly z pedopatologie (4), Experimentální pedagogika (4), Stern: Methodensammlung (2), Čtení a výklad Claparédova díla La psychologie de l'enfant (2).

Turdý: Moderní filosofie náboženství (2), Aristotelova filosofie a její význam ve vývoji filosofie (2).

Chalupný: Zákony sociologického vývoje (2), Sociologie práva a mravnosti (1). Rostohar: Locke: Zkoumání o rozumu lidském (2), Psychofysika. Metody (1), Seminární cvičení (4).

Vědy filologické

Novotný: Úvod do čtení Platona (2).

Ak. rok 1924/25

Bláha: Praktická filosofie (4), Základy sociologie (společenská statika): společenská organizace (rodina, národ, stát), společenské soustavy (právo, mravnost, náboženství (2, 3), Seminární cvičení (2).

Chlup: Dějiny pedagogických teorií nové doby $(1,1)$, Základy středoškolské pedagogiky $(4,4)$, Čtení a výklad Thorndikeovy pedagogické psychologie (2). Turdý: Konkretní logika. Principy třídění věd (2), Masarykova filosofie (2), Seminář filosofický (2).

Rostohar: Psychologie (5), Logika (5), Čtení a výklad spisů filosofických (2, 2), Psychologické cvičení (2).

Chalupný: Sociologie práva a mravnosti (1).

Seminář pro klasickou filologii

Svoboda: Filosofie doby helenistické (2).

Ak. rok 1925/26

Rostohar: Psychologie (4, 3), O metodách experimentální psychologie (1, 2), Čtení a výklad spisů filosofických (2, 2), Cvičení psychologická (2, 2).

Bláha: Praktická filosofie (4), Základy sociologie (sociální vývoj, sociální patologie) (2, 3), Základy žurnalismu (2), Seminární cvičení (2, 2).

Tordý: Moderní problémy noetické (2), Iracionalistická filosofie (Bergson) (2). Chlup: Dějiny pedagogiky v době nejnovější (1), Středoškolská didaktika 
$(4,4)$, Nejnovější školské reformy (1), Seminární cvičení (2).

Chalupný: Z italské sociologie (1).

Uher: Metody práce pedagogické (1), Metody mravní výchovy (2), Sociologické základy pedagogiky (2).

Seminář pro klasickou filologii

Svoboda: ̌̌ecká filosofie od Thaleta po sofisty (2).

doc. PhDr. Jiří Gabriel, CSc.

Brno, Česká republika

jgab@post.cz 